\title{
Article
}

\section{Assessment of Soil Contamination with Potentially Toxic Elements and Soil Ecotoxicity of Botanical Garden in Brno, Czech Republic: Are Urban Botanical Gardens More Polluted Than Urban Parks?}

\author{
Vaclav Pecina ${ }^{1,2}\left(\mathbb{D}\right.$, Martin Brtnicky ${ }^{1,2,3, *(\mathbb{D}}$, Marie Balkova $\left.{ }^{3}{ }^{(}\right)$, Jitka Hegrova ${ }^{4}\left(\mathbb{D}\right.$, Martina Buckova ${ }^{4}$, \\ Tivadar Baltazar ${ }^{2}\left(\mathbb{D}\right.$, Roman Licbinsky $^{4}\left(\mathbb{D}\right.$ and Maja Radziemska ${ }^{2,5, * \mathbb{D}}$
}

1 Faculty of Chemistry, Institute of Chemistry and Technology of Environmental Protection, Brno University of Technology, Purkynova 118, 61200 Brno, Czech Republic; xcpecina@fch.vut.cz

2 Department of Agrochemistry, Soil Science, Microbiology and Plant Nutrition, Faculty of AgriSciences, Mendel University in Brno, Zemedelska 1, 61300 Brno, Czech Republic; tivadar.baltazar@mendelu.cz

3 Department of Geology and Soil Science, Faculty of Forestry and Wood Technology, Mendel University in Brno, Zemedelska 3, 61300 Brno, Czech Republic; marie.balkova@mendelu.cz

check for

updates

Citation: Pecina, V.; Brtnicky, M.; Balkova, M.; Hegrova, J.; Buckova, M.; Baltazar, T.; Licbinsky, R.;

Radziemska, M. Assessment of Soil Contamination with Potentially Toxic Elements and Soil Ecotoxicity of Botanical Garden in Brno, Czech Republic: Are Urban Botanical Gardens More Polluted Than Urban Parks? Int. J. Environ. Res. Public Health 2021, 18, 7622. https:// doi.org/10.3390/ijerph18147622

Academic Editors: Bozena Smreczak, Alicja Kicinska, Eleonora Wcisło and Giulia Maisto

Received: 21 April 2021

Accepted: 14 July 2021

Published: 17 July 2021

Publisher's Note: MDPI stays neutral with regard to jurisdictional claims in published maps and institutional affiliations.

Copyright: () 2021 by the authors. Licensee MDPI, Basel, Switzerland. This article is an open access article distributed under the terms and conditions of the Creative Commons Attribution (CC BY) license (https:// creativecommons.org/licenses/by/ $4.0 /)$.
4 Transport Research Centre, Lisenska 33a, 63600 Brno, Czech Republic; jitka.hegrova@cdv.cz (J.H.); martina.buckova@cdv.cz (M.B.); roman.licbinsky@cdv.cz (R.L.)

5 Institute of Environmental Engineering, Warsaw University of Life Sciences, 159 Nowoursynowska, 02-776 Warsaw, Poland

* Correspondence: martin.brtnicky@seznam.cz (M.B.); maja_radziemska@sggw.edu.pl (M.R.); Tel.: +420-607-036-907 (M.B.); +48-2259-353-70 (M.R.)

Abstract: Though botanical gardens are an important and widely visited component of urban green spaces (UGS) worldwide, their pollution is rarely studied. The aim of this study was to assess botanical garden soil contamination and ecotoxicity and to evaluate whether urban botanical gardens are more contaminated than urban parks. Soil assessments showed serious contamination with $\mathrm{Cd}$, $\mathrm{Pb}$ and $\mathrm{Zn}$, emitted predominantly by traffic, agrochemicals and past construction and demolition waste. The discovery of hazardous historical ecological burden in the UGS calls for the necessity of detailed surveys of such areas. Despite prevailing moderate-to-heavy contamination, the soil was only slightly ecotoxic. Maximum immobilisation inhibition of Daphnia magna reached 15\%. Growth of Sinapis alba L. was predominantly stimulated (73\%), and Desmodesmus subspicatus Chodat was exclusively stimulated, possibly due to soil alkalinity and fertiliser-related nutrients. The hypothesis of a higher contamination of urban botanical gardens compared to urban parks was confirmed. However, urban parks can face a greater risk of soil ecotoxicity, hypothetically due to decreased activity of soil organisms resulting from adverse soil conditions caused by active recreation. The results highlight the need for an increased focus on botanical and ornamental gardens when assessing and managing UGS as areas potentially more burdened with contamination.

Keywords: urban green spaces; ornamental garden; soil toxicity; construction and demolition waste; contamination; risk assessment

\section{Introduction}

Urban soil pollution by anthropogenic activities is an important research topic [1,2]. Reduced soil quality poses a risk to human health and urban ecosystems [3-6]. Typically, soil in industrial areas or near roads contains the highest pollution levels due to the continuous emission of potentially toxic elements (PTEs) $[7,8]$. Industry, traffic $[9,10]$ and coal combustion $[4,10]$ emit high concentrations of PTEs and represent the most important sources of pollution in cities.

Urban green spaces (UGS) and their soils are an essential component of urban ecosystems $[3,11,12]$. They improve city dwellers' living conditions through functions such as 
climate regulation, sustaining biogeochemical cycles, water flow regulation, runoff mitigation and pollutant retention [6,11,13-15]. UGS are often considered less polluted [16,17] and sometimes even used to determine background values for environmental contamination assessment $[18,19]$. However, due to their potential to retain and store pollutants, they may become hotspots of accumulated pollution. PTEs bind to the soil organic matter [1] of UGS and remain persistent in soil [20].

When assessing UGS pollution with PTEs, great attention is paid to public urban parks (e.g., Setälä et al. [6]; Urrutia-Goyes et al. [21]; Gu et al. [22]; Brtnický et al. [23]; Han et al. [24]). However, research rarely focuses on arboretums, botanical and ornamental gardens $[10,25]$, despite their worldwide prevalence in urban areas and importance to local communities.

Botanical gardens and arboretums represent artificial but stable environments [26]. They were first introduced in the 16th century. There are 1775 registered in 148 countries according to the current definition of Botanic Gardens Conservation International [27], and more than 3000 have been registered according to the previous definition [28]. In addition to their focus on scientific research, conservation and education, botanical gardens and arboretums are popular tourist sites visited by approximately 500 million visitors per year [27] with a strong social relevance [29,30]. Cavender and Donnelly [13] even urge their increased involvement with urban forestry to improve sustainability of cities and human lives.

The greater focus on urban parks research may be due to residents' higher frequency of visits, thus increasing the risk of exposure to soil pollutants. Additionally, the possibility of direct contact with contaminated soil is usually less likely in botanical gardens owing to the different nature of activities. Active and regular management of botanical gardens through fertilisers and various pesticides $[9,25,26]$, on the other hand, can result in a higher risk of soil contamination. For example, Orecchio [31] found botanical garden soil contaminated with polycyclic aromatic hydrocarbons. Similarly, the potential of a higher load of PTEs in ornamental gardens was indicated by Biasioli et al. [32]. Martín et al. [10] even refer to botanical gardens as excellent tools to evaluate pollution. Thus, despite the lower risks to visitors, botanical gardens can hypothetically be more hazardous contamination hotspots of PTEs in urban areas.

To verify this hypothesis, several sub-steps were performed: (1) assessment of soil contamination with PTEs (As, Cd, Cr, Cu, Ni, Pb and $\mathrm{Zn}$ ) in the botanical garden, (2) assessment of the spatial distribution of PTEs, (3) assessment of the soil ecotoxicity and (4) comparison of the contamination of botanical and ornamental gardens to urban parks.

\section{Materials and Methods}

\subsection{Study Site}

The studied botanical garden (and arboretum) is located in Brno, Czech Republic, at an altitude of 220-250 m a. s. 1 . in an area with an average total precipitation of approximately $550 \mathrm{~mm} /$ year and average annual temperature of $8.4^{\circ} \mathrm{C}$. The soil is primarily clayey with a high $\mathrm{CaO}$ content or artificial batch formed after clay mining. The arboretum was founded in 1938 on two hectares and was extended to eleven hectares in 1967. Until then, the area had a predominantly agricultural use. The lower section of the garden was adjacent to the construction landfill, and demolition waste remained after the bombing of the city during World War II. The northern section was bordered by an allotment and an agricultural area. Currently, a university campus, a dormitory, a sports area, an unmanaged green space, roads and tram tracks surround the garden. The garden grounds include an administrative building with classrooms, greenhouses and water features. It serves as a purpose-built educational facility and is also used by students for recreation and relaxation.

\subsection{Soil Sampling and Laboratory Analysis}

A total of 37 samples were collected from the botanical garden topsoil $(0-5 \mathrm{~cm})$, and two comparative samples were collected near the road and tram stops outside the garden. The 
samples were taken from the regular sampling network with a $5 \mathrm{~m}$ spacing (Figure 1 ). Three subsamples within a radius of $0.5 \mathrm{~m}$ from the sampling point were collected and subsequently mixed into one composite sample. Each composite sample consisted of 500-1000 g of soil. The samples were dried at room temperature and sieved through a nylon sieve $(2 \mathrm{~mm}$ mesh size) for water extraction and then milled to a fine fraction in an oscillatory mill for the aqua regia extraction.

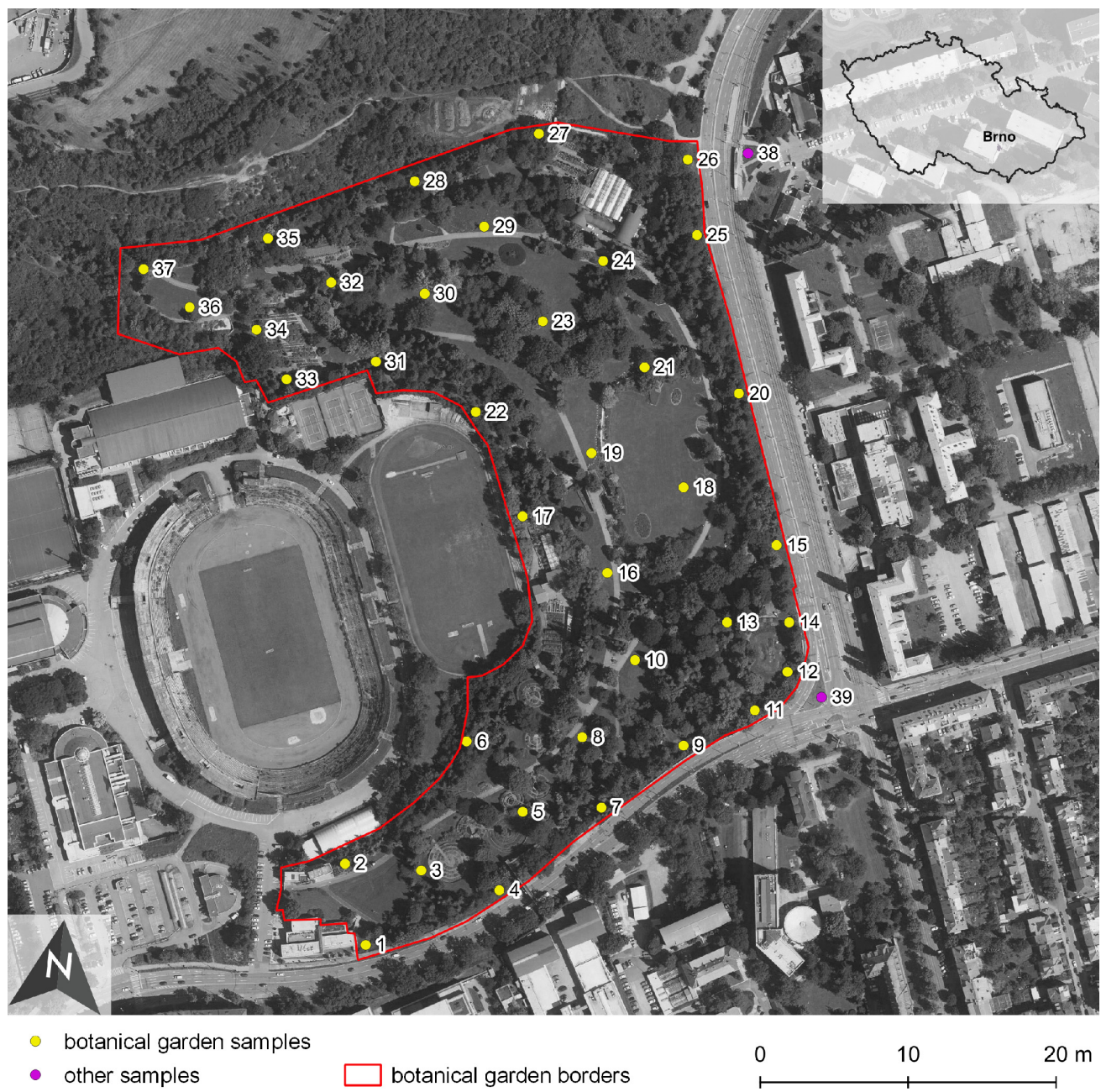

Figure 1. Study site with sampling points in the context of the surrounding urban area.

For trace element analysis, about $1 \mathrm{~g}$ of dry milled soil sample was digested in aqua regia mixture (prepared from subboiled ultrapure acids) in a high-pressure, high-temperature microwave digestion system SW-4 (Berghof, Eningen, Germany). The procedure followed ISO 11466:1995 [33]. The digested samples were diluted to a final volume of $100 \mathrm{~mL}$ with ultrapure water (Merck Millipore, Darmstadt, Germany). The digestion blank was prepared in parallel and was subtracted during evaluation.

Elemental determination was performed using a triple quadrupole inductively coupled plasma mass spectrometer ICP-MS/MS (Agilent Technologies, WaldBronn, Germany). Selected isotopes ${ }^{75} \mathrm{As},{ }^{52} \mathrm{Cr},{ }^{60} \mathrm{Ni},{ }^{65} \mathrm{Cu},{ }^{66} \mathrm{Zn},{ }^{111} \mathrm{Cd}$ and ${ }^{208} \mathrm{~Pb}$, were measured in $\mathrm{O}_{2}$ reaction gas $(0.29 \mathrm{~mL} / \mathrm{min})$ and He collision gas $(4 \mathrm{~mL} / \mathrm{min})$ modes. The forwarded RF power was $1550 \mathrm{~W}$, with a carrier gas flow rate of $1.07 \mathrm{~L} / \mathrm{min}$ and integration time per isotope was $0.3 \mathrm{~s}$. A calibration range of $0-100 \mu \mathrm{g} / \mathrm{L}$ for all elements was prepared by mixing from a $1.000 \mathrm{~g} / \mathrm{L}$ single standard stock solution (Analytika, Prague, Czech Republic) in a matrix of $2 \% \mathrm{HNO}_{3}$ (ultrapure) and $0.35 \% \mathrm{HCl}$ (ultrapure). The internal standard solution was prepared in a final concentration of $100 \mu \mathrm{g} / \mathrm{L}$ as a mixture of Bi, Ge, In, Li, Sc, Tb, Y. Quality control was performed using reference materials (I) SRM 1640a Trace Elements 
in Natural Water (National Institute of Standards \& Technology, Gaithersburg, MD, USA) for instrument settings and calibrations and during measurement for control of signal stability, and (II) QCM Metranal 33 Clay-loamy soil (Analytika, Prague, Czech Republic) with a certified content of elements leachable by the aqua regia used for control of the whole procedure (digestion and analysis).

For ecotoxicological characterisation, water extraction in a Reax 20 rotary shaker (Heidolph Instruments, Schwabach, Germany) was carried out using $10.0 \mathrm{~g}$ of dry sieved soil sample and $100 \mathrm{~mL}$ of ultrapure water (Merck Millipore, Darmstadt, Germany) for $24 \mathrm{~h}$ at laboratory temperature. Extracts were subsequently centrifuged by Universal $320 \mathrm{R}$ benchtop centrifuge (Hettich, Kirchlengern, Germany) for $20 \mathrm{~min}$ at the rotation speed of $4000 \mathrm{rpm}$ and then filtered through a $5 \mu \mathrm{m}$ paper filter. The filtered aqueous extracts' $\mathrm{pH}$ was measured on a laboratory $\mathrm{pH} / \mathrm{Conductometer}$ Orion 4 Star with a glass combination electrode. The $\mathrm{pH}$ measurement was performed according to ISO 10523:2010 [34].

Total organic carbon (TOC) was measured using a TOC analyser soli TOC $^{\circledR}$ cube (Elementar Analysensysteme GmbH, Langenselbold, Germany).

\subsection{Soil Contamination Assessment}

The soil contamination assessment was carried out by Geoaccumulation Index ( $\left.\mathrm{I}_{\text {geo }}\right)$, which assesses soil contamination by comparing the current and expected pre-industrial PTE contents. The index is calculated as follows [35]:

$$
\mathrm{I}_{\text {geo }}=\log _{2}\left(\frac{\mathrm{C}_{\mathrm{i}}}{1.5 \mathrm{~B}_{\mathrm{i}}}\right)
$$

where Ci represents the content of the PTE, 1.5 represents the constant reflecting natural fluctuations of the PTE content and Bi represents the content of the corresponding PTE in the background. The background values of $\mathrm{Cd}, \mathrm{Cu}, \mathrm{Pb}$ and $\mathrm{Zn}$ were taken from the study by Brtnický et al. [23], who conducted research in a nearby park (Luzanky Park). To determine the background values for $\mathrm{As}, \mathrm{Cr}$ and $\mathrm{Ni}$, two soil samples from a depth of 100 $\mathrm{cm}$ were taken and analysed from the same locality. The $\mathrm{I}_{\text {geo }}$ classes are as follows $[2,26]$ : $\mathrm{I}_{\text {geo }} \leq 0$ : uncontaminated; $0<\mathrm{I}_{\text {geo }} \leq 1$ : uncontaminated to moderately contaminated; $1<$ $I_{\text {geo }} \leq 2$ : moderately contaminated; $2<$ Igeo $\leq 3$ : moderately to heavily contaminated; $3<$ $\mathrm{I}_{\text {geo }} \leq 4$ : heavily contaminated; $4<\mathrm{I}_{\text {geo }} \leq 5$ : heavily to extremely contaminated; $\mathrm{I}_{\text {geo }}>5$ : extremely contaminated.

\subsection{Soil Ecotoxicity Assessment}

Soil toxicity was assessed using acute ecotoxicity tests on three selected organisms representing different trophic levels: water planktonic crustacean Daphnia magna, freshwater green alga Desmodesmus subspicatus Chodat and the seeds of Sinapis alba L. The tests were performed on aqueous extracts of soil samples to evaluate the effect of water-leachable substances from soils on the organisms because of the greater importance of the bioavailable fraction of PTEs compared to the total soil PTE contents for risk assessment [36].

The D. magna crustacean test carried out according to ISO 6341:2013 [37] determined the effect of aqueous soil extracts on mortality and immobilisation of the organism. The test was run for $48 \mathrm{~h}$ at $20^{\circ} \mathrm{C}$, without aeration, light or feeding. The age of the tested organisms was a maximum of $24 \mathrm{~h}$ at the time of testing.

The test on the alga D. subspicatus was performed in microtiter serological plates according to ISO 8692:2012 [38]. Aqueous extracts of soils inoculated with algae and control populations (nutrient solution with added algae) were incubated by shaking them in a thermostat under constant illumination of 8000 lux at $23{ }^{\circ} \mathrm{C}$ for $72 \mathrm{~h}$. Cell density conversion was used to calculate algal growth rates. Algal growth inhibition was calculated by comparing algal growth rates in aqueous soil extracts to the control population's growth rate.

Tests on S. alba seeds were performed according to the Methodical Instruction of the Ministry of the Environment of the Czech Republic [39]. The test consisted of culturing 
the seeds under standard conditions in Petri dishes on filter paper saturated with aqueous soil extract and assessing the effect on seed germination and root growth. The plates were cultured for $72 \mathrm{~h}$ in a thermostat without light at a temperature of $20^{\circ} \mathrm{C}$. Inhibition or stimulation of root growth for a given sample was calculated by comparing the average root length in plates containing the test sample of aqueous soil extract against the average root length in control plates.

\subsection{Spatial and Statistical Analysis}

A vector point layer was created with the attribute table containing information on $\mathrm{As}, \mathrm{Cd}, \mathrm{Cr}, \mathrm{Cu}, \mathrm{Ni}, \mathrm{Pb}$ and $\mathrm{Zn}$ soil contents. These sampling points were arranged into a regular net with a grid size of $0.1 \times 0.1 \mathrm{~km}$. Interpolation data analyses were performed using QGIS Desktop 3.4.13 software. Spline [40,41] was chosen as the geostatistical method for spatial interpolation. More specifically, the method with b-spline refinement and 0.0001 threshold error was selected. The spatial resolution of calculated output rasters was $0.1 \mathrm{~m}$. These rasters were interpreted into colourful images based on quantile distribution into ten value classes.

Additional data processing and advanced statistical analysis were carried out using the statistical program R version 4.0.2. [42]. Multiple linear regression analysis was performed for modelling the relationship between the species immobilisation or inhibition with the dependence of $\mathrm{I}_{\text {geo }}$ of PTEs. The strength of the linear relationship between the PTEs and $\mathrm{pH}$ and TOC was measured by Pearson's correlation coefficient. The principal component analysis (PCA) was implemented for reducing the number of variables of PTEs in used datasets. The comparison between the botanical garden and the park was made using the Tukey Honest Significant Difference (Tukey HSD) test at $p=0.05$.

\section{Result and Discussion}

\subsection{Soil Contamination Assessment}

The results of the soil contamination assessment in the botanical garden are presented in Table 1. All the median values were below the limits [43], indicating an overall low level of pollution and risk. However, due to the very low background values, serious contamination is evident from the assessment using $\mathrm{I}_{\text {geo }}$ in some PTEs. Although As content levels were categorised as 'uncontaminated', indicating low enrichment from coal combustion [44,45], $\mathrm{Ni}, \mathrm{Cr}$ and $\mathrm{Cu}$ levels ranged from 'uncontaminated' to a 'moderately contaminated' category. Cd content measured as 'moderately contaminated', $\mathrm{Pb}$ was 'moderately contaminated' to 'heavily contaminated' and Zn measured as 'heavily contaminated' to an 'extremely contaminated' category.

Table 1. PTE contents (mg/kg) in botanical garden soils, garden surroundings, standards (DSG = Dutch Soil Guidelines), contamination assessment ( $\mathrm{I}_{\text {geo }}$ ) and PTE contents in other gardens (mean values in $\mathrm{mg} / \mathrm{kg}$ ).

\begin{tabular}{cccccccc}
\hline Data & As & $\mathbf{C d}$ & $\mathbf{C r}$ & $\mathbf{C u}$ & $\mathbf{N i}$ & $\mathbf{P b}$ & $\mathbf{Z n}$ \\
\hline Average & 10.3 & 0.61 & 52.2 & 37.7 & 33.8 & 38.1 & 172 \\
S.D. & 1.99 & 0.61 & 8.32 & 69.8 & 4.91 & 13.4 & 219 \\
Minimum & 6.68 & 0.18 & 38.1 & 16.3 & 25.0 & 15.6 & 75.6 \\
Median & 10.2 & 0.43 & 50.3 & 24.0 & 33.4 & 35.4 & 717 \\
Maximum & 14.7 & 3.51 & 75.3 & 453 & 47.2 & 75.8 & 1414 \\
\hline Reference Traffic Sites $_{\text {Background }}$ & 13.7 & 0.40 & 65.3 & 29.6 & 39.6 & 52.5 & 132 \\
\hline DSG Target Value $^{2}$ & 6.92 & $0.15^{1}$ & 29.3 & $14.6^{1}$ & 21.3 & $3.2^{1}$ & $5.5^{1}$ \\
DSG Intervention Value $^{2}$ & 29 & 0.8 & 100 & 36 & 35 & 85 & 140 \\
\hline Igeo $_{\text {gași Botanical Garden }}{ }^{3}$ & 55 & 12 & 380 & 190 & 210 & 530 & 720 \\
\hline Harbin Botanical Garden $^{4}$ & -0.04 & 1.09 & 0.23 & 0.30 & 0.05 & 2.90 & 4.03 \\
\hline
\end{tabular}

${ }^{1}$ Brtnický et al. [23]; ${ }^{2}$ VROM [43]; ${ }^{3}$ Apostoae [25]; ${ }^{4}$ Meng et al. [8]. 
A similar grouping of the elements as in the $\mathrm{I}_{\text {geo }}$ assessment was also presented in the PCA (Figure 2). As, Ni and $\mathrm{Cr}$ formed one group of strongly correlated elements (Table 2) with low $\mathrm{I}_{\text {geo }}$ values, indicating a predominantly geogenic origin. The second group consisting of $\mathrm{Cd}, \mathrm{Pb}, \mathrm{Cu}$ and $\mathrm{Zn}$ was affected by the anthropogenic activities due to the increased $\mathrm{I}_{\text {geo }}$ values (Table 1). The overall low importance of soil pH (Figure 2) can be attributed mainly to the soil alkalinity (pH 7.8-9.0, average 8.2); PTEs relationships with $\mathrm{pH}$ were insignificant (Table 2). Positive correlations of PTEs with TOC (TOC 2.2-18.1\%, average 5.7\%) (Table 2) demonstrated their binding to soil organic matter [1].

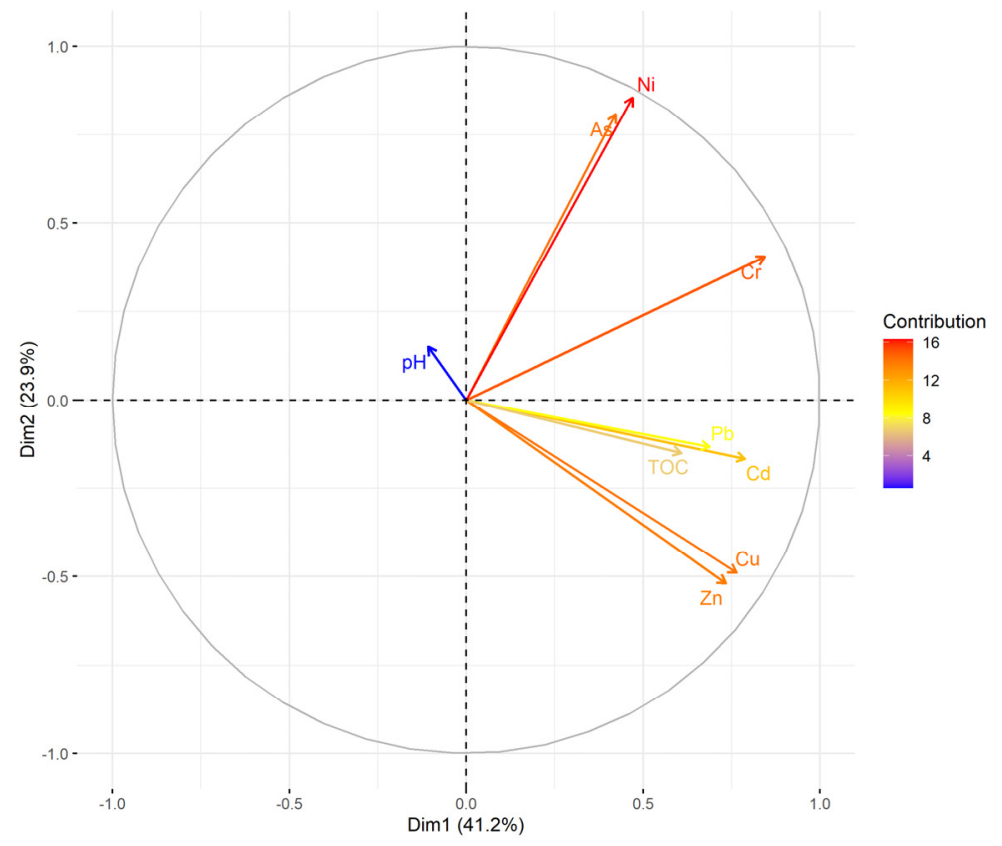

Figure 2. PCA biplot of $\mathrm{pH}$, TOC and PTEs.

Table 2. Correlation matrix of the soil PTE contents; * significant at $p=0.05 ;{ }^{* *}$ significant at $p=0.01$; *** significant at $p=0.001$.

\begin{tabular}{ccccccccc}
\hline As & 0.09 & $0.64^{* * *}$ & 0.01 & $0.83^{* * *}$ & 0.22 & -0.03 & 0.01 & 0.01 \\
& $\mathrm{Cd}$ & $0.54^{* * *}$ & $0.53^{* * *}$ & 0.25 & $0.45^{* *}$ & $0.48^{* *}$ & -0.09 & $0.74^{* * *}$ \\
& $\mathrm{Cr}$ & $0.50^{* *}$ & $0.75^{* * *}$ & $0.43^{* *}$ & $0.46^{* *}$ & -0.08 & $0.34^{*}$ \\
& & $\mathrm{Cu}$ & -0.06 & $0.53^{* * *}$ & $0.95^{* * *}$ & -0.13 & 0.30 \\
& & & $\mathrm{Ni}$ & 0.18 & -0.11 & 0.11 & 0.19 \\
& & & & $\mathrm{~Pb}$ & $0.50^{* *}$ & -0.16 & 0.29 \\
& & & & & $\mathrm{Zn}$ & -0.01 & $0.34^{*}$ \\
& & & & & & $\mathrm{pH}$ & 0.01 \\
& & & & & & & \\
& & & & & & & & \\
& & & & & & &
\end{tabular}

The results of the spatial distribution (Figure 3) showed mutual spatial relationships. All the PTEs reached increased values in the southeast part of the botanical garden near a busy crossroad. Such places are highly contaminated with PTEs and other pollutants due to stop-and-go traffic $[17,19,46,47]$. Road and tram traffic are a likely source of this enrichment with PTEs as one of the main emitters of urban contamination [5,19,48,49]. Road traffic is a primary source of $\mathrm{Cd}, \mathrm{Cr}, \mathrm{Cu}, \mathrm{Ni}, \mathrm{Pb}$ and $\mathrm{Zn}[46,47]$, and tram or train traffic emits a similar spectrum of metals [50]. Malkoc et al. [49] reported that tram traffic-related contamination does not reach levels as high as road levels, but the combination causes the highest contamination. The contamination originating from traffic is also indicated by slightly increased PTE values (especially $\mathrm{Pb}$ ) in the referenced traffic sites compared to the garden corresponding median values. A significant correlation of $\mathrm{Pb}$ with $\mathrm{Zn}$ (Table 2) may 
be associated primarily with leaded petrol's historical use [10,48]. The strong relationship between $\mathrm{Zn}$ and $\mathrm{Cu}$ is attributed to their presence in deteriorating brake components [5].

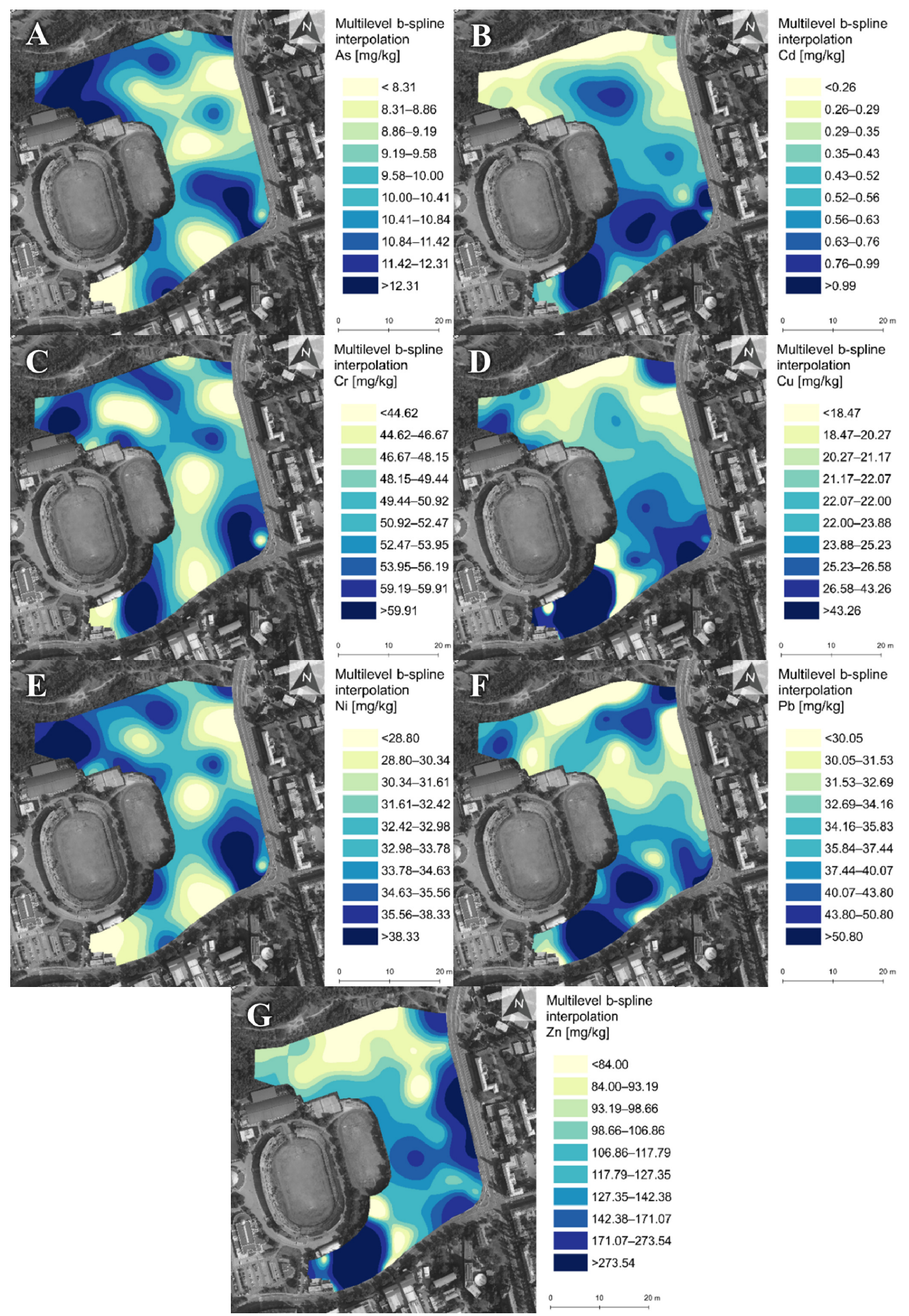

Figure 3. Spatial distribution of $\mathrm{As}(\mathbf{A}), \mathrm{Cd}(\mathbf{B}), \mathrm{Cr}(\mathbf{C}), \mathrm{Cu}(\mathbf{D}), \mathrm{Ni}(\mathbf{E}), \mathrm{Pb}(\mathbf{F})$ and $\mathrm{Zn}(\mathbf{G})$ in the botanical garden soils.

There is a considerable increase in $\mathrm{Cd}, \mathrm{Cr}, \mathrm{Cu}, \mathrm{Pb}$ and $\mathrm{Zn}$ values in the southwest part of the botanical garden. The extreme values above DSG Intervention Value (Table 1, Cu and $\mathrm{Zn}$ reached maximum levels) indicate serious pollution. The origin of this pollution is probably underlying construction and demolition waste. A similar situation of botan- 
ical garden contamination by waste material is mentioned by Bretzel and Calderisi [48]. Cachada et al. [5] referred to increased $\mathrm{Cu}, \mathrm{Pb}$ and $\mathrm{Zn}$ contents in ornamental gardens, potentially originating from previous industrial activity. These findings highlight the importance of UGS investigation and the history of their surroundings, as UGS can be seriously polluted by historical and often forgotten burdens.

Other elevated PTE levels (Figure 3) corresponded with more intensively managed zones of the botanical garden (especially in the northwest), signalling possible origin from agricultural chemicals. In addition to $\mathrm{Cu}$ and $\mathrm{Zn}$, originating from the traffic, a strong correlation indicates their common source from fertilisers containing these elements as essential nutrients supporting plant growth. Historically, due to limited or non-existent legislation, applications of fertilisers and various pesticides were uncontrolled and could have contributed to soil contamination. Such contamination was reported by Apostoae [25].

Comparison to other botanical gardens is limited in scope due to the low number of studies presenting PTE values (Table 1). However, available evidence shows similar values without extreme deviations, indicating overall low pollution levels according to DSG Intervention Values [43].

\subsection{Soil Ecotoxicity Assessment}

Due to the low PTE values below the soil quality standards (Table 1), no ecotoxicity risk could be expected. However, soil is a complex system, and its ecotoxicity reflects the toxicity of all present substances, not only PTEs. Soil ecotoxicity is an expression of both synergic and antagonistic contaminants' effect on organisms, their interactions upon the soil matrix and upon tested organisms [51,52]. Thus, chemical analysis results do not necessarily correlate with the results of ecotoxicological tests, specifically in soil where the degree of pollution is not very high [51].

Maximum immobilisation inhibition of D. magna reached $15 \%$ and was only $0-5 \%$ in $89 \%$ of cases (Figure 4 ). Increasing contamination with $\mathrm{Ni}$ ( $\mathrm{I}_{\text {geo }}>0$ ), despite its overall low level, led to the immobilisation of D. magna in more than $70 \%$ of cases as it is a highly toxic element to crustaceans $[53,54]$. Continued contamination with $\mathrm{Ni}$ can be expected to negatively affect the vitality of crustacean populations in the botanical garden water features. There were only growth stimulation effects recorded in the test using algae D. subspicatus (Figure 4). Therefore, the contamination of the botanical garden does not pose a serious risk to aquatic organisms.

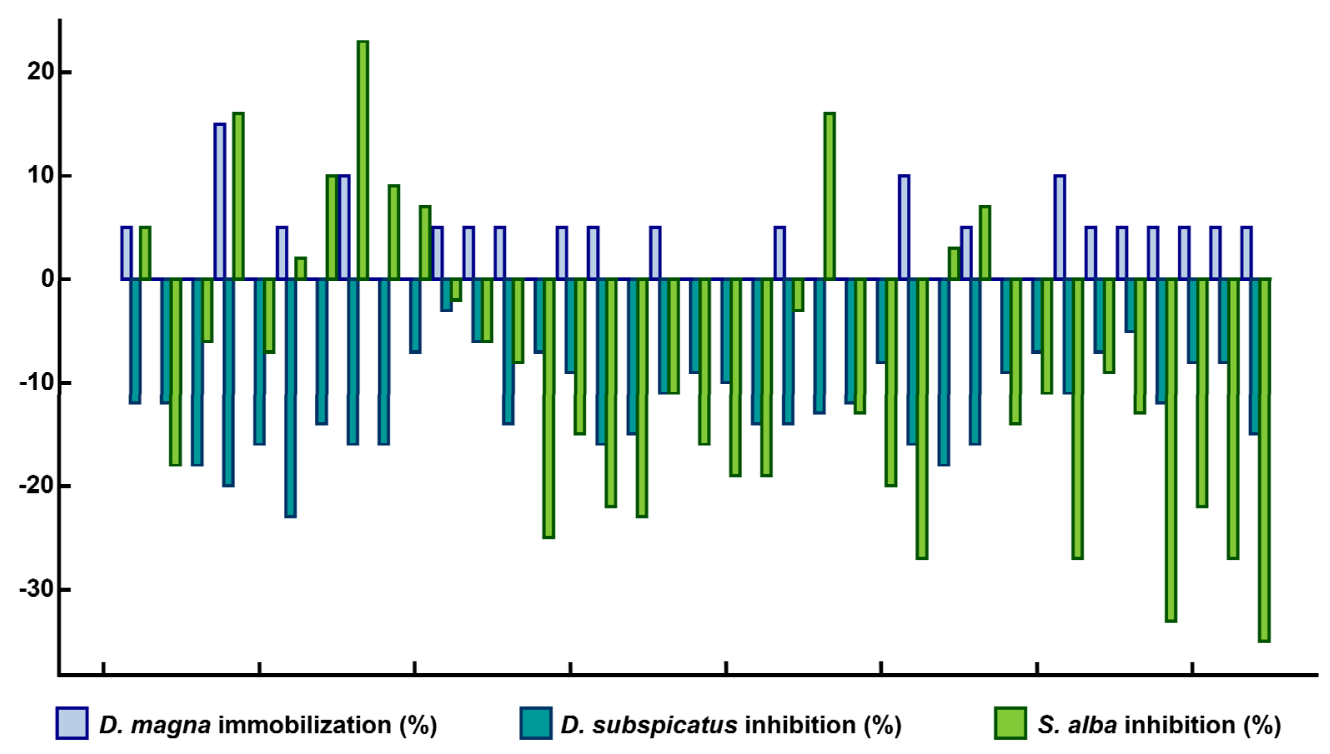

Figure 4. Soil ecotoxicity assessment using Daphnia magna, Desmodesmus subspicatus and Sinapis alba; negative values indicate growth stimulation. 
Similarly, slight toxic effects were recorded in the phytotoxicity test using S. alba (Figure 4). The plant growth was stimulated in $73 \%$ of cases and maximum growth inhibition reached $23 \%$. Thus, the soil contamination posed only a slight phytotoxic risk for plants growing in the botanical garden.

Soil ecotoxicity assessment indicated a low level of PTEs-related threat. However, this threat may be slightly underestimated due to the alkaline nature of the soils. Metal bioavailability is a key factor in determining the metal's toxicity and uptake by organisms [54] and is significantly affected by soil properties such as $\mathrm{pH}$ [48]. Such alkaline soil as in this case limits the presence of fractions of water-soluble soil contaminants in aqueous soil extracts [55]. Therefore, the overall PTEs bioavailability could be reduced, and the results showed decreased toxicity effect on the tested organisms. The frequently observed stimulation of both algae and S. alba's growth may be due to the higher content of nutrients in the soil originating from fertilisers. Aruoja et al. [56] state that the harmful effect of PTEs on organisms can be masked in soils containing a high concentration of nutrients/supplements.

\subsection{Comparison of Contamination of Urban Botanical Gardens and Urban Parks}

To verify the hypothesis of higher soil contamination in botanical gardens compared to urban parks, the results were compared with the neighbouring park studied by Brtnický et al. [23]. Despite the negligible difference in distance, the botanical garden soils were significantly more contaminated with $\mathrm{Cd}, \mathrm{Cu}, \mathrm{Pb}$ and $\mathrm{Zn}$ (Figure 5). This result is consistent with other available studies (Table 3). In the botanical garden in Iași, $\mathrm{Cd}$ and $\mathrm{Cu}$ contents were $4.7 \times$ and $2 \times$ higher than in the nearby urban park.
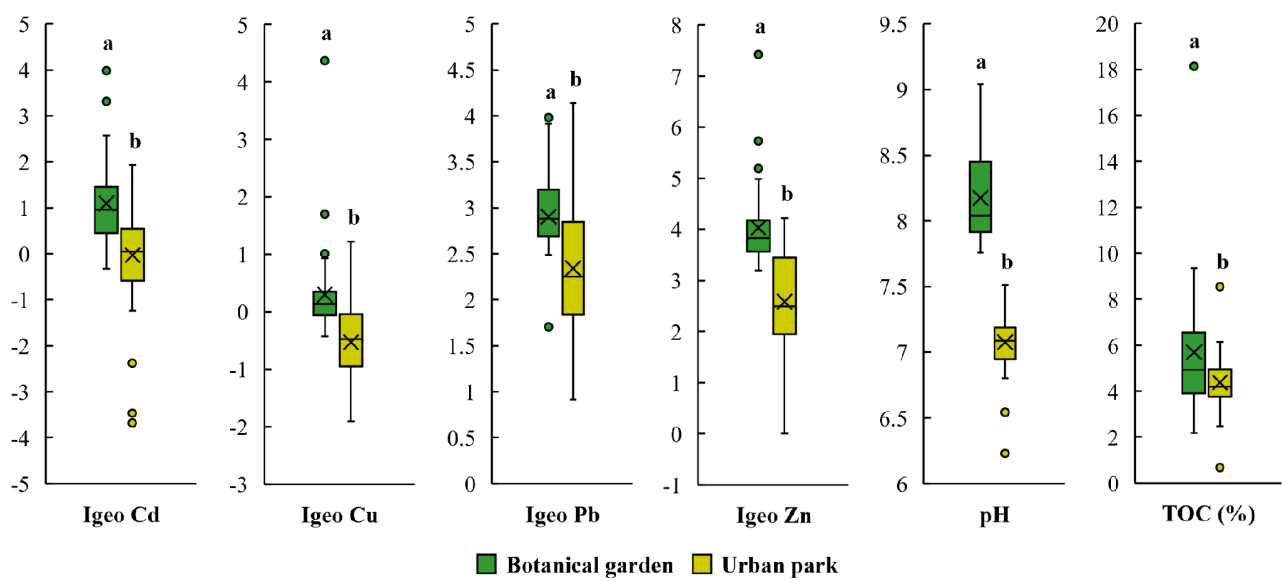

Figure 5. Comparison of PTE contamination (using Geoaccumulation Index, Igeo), pH and TOC of botanical garden and urban park topsoil; different letters indicate significant differences at $p=0.05$, Tukey HSD test.

Higher PTE values were found in the botanical garden even though the park was approximately 150 years older with the potential for more prolonged accumulation of PTEs and higher soil contamination levels $[6,7,16]$. The park is also surrounded by busier roads which were previously identified as primary sources of contamination. Therefore, the dominant reason for the higher contamination of the botanical garden is likely its management. Maintenance practices, including the use of various fertilisers and sprays, are also mentioned by Imperato et al. [9], Ruiz-Cortes et al. [57], Biasioli et al. [32] and Rodrigues et al. [1] as a source of contamination in square and ornamental gardens. Furthermore, the application of organic amendments and related significantly higher organic carbon content in the botanical garden topsoil compared to the park (Figure 5) could induce higher retention of PTEs [1] and their accumulation. The results of this and other studies (Table 3) confirm the hypothesis of higher contamination of botanical gardens compared to urban parks and attribute more intensive management as the primary cause. 
Table 3. Comparison of urban parks and botanical (or ornamental) gardens PTE contents (mg/kg). Lowercase letters indicate significant differences between their PTE contents at 0.05 (Tukey HSD test) when comparing urban gardens and urban parks in the PTE contents with non-available values: $\mathrm{H}=$ Higher content and $\mathrm{L}=$ Lower content.

\begin{tabular}{|c|c|c|c|c|c|c|c|c|c|}
\hline \multirow{2}{*}{ City } & \multicolumn{4}{|c|}{ Botanical Garden } & \multicolumn{4}{|c|}{ Urban Park } & \multirow{2}{*}{ Justification } \\
\hline & $\mathrm{Cd}$ & $\mathrm{Cu}$ & $\mathbf{P b}$ & Zn & $\mathrm{Cd}$ & $\mathrm{Cu}$ & $\mathrm{Pb}$ & $\mathrm{Zn}$ & \\
\hline Brno & $0.61 \mathrm{a}$ & $37.7 \mathrm{a}$ & $38.1 \mathrm{a}$ & $172 \mathrm{a}$ & $0.28^{1} \mathrm{~b}$ & $16.6^{1} \mathrm{~b}$ & $27.2^{1} \mathrm{~b}$ & $59.0^{1} \mathrm{~b}$ & See the text \\
\hline Iași & $0.36^{2}$ & $73.5^{2}$ & $33.8^{2}$ & $113^{2}$ & $0.08^{3}$ & $37.5^{3}$ & $46.7^{3}$ & $217^{3}$ & N.A. \\
\hline Naples 4 & - & $\mathrm{H}$ & $\mathrm{H}$ & $\mathrm{H}$ & - & $\mathrm{L}$ & $\mathrm{L}$ & $\mathrm{L}$ & $\begin{array}{c}\text { Park soils were } \\
\text { better protected } \\
\text { from } \\
\text { contamination. } \\
\text { Park soils were }\end{array}$ \\
\hline $\begin{array}{l}\text { Ljubljana, Sevilla } \\
\text { and Torino }\end{array}$ & - & $\mathrm{H}$ & $\mathrm{H}$ & $\mathrm{H}$ & - & $\mathrm{L}$ & $\mathrm{L}$ & $\mathrm{L}$ & $\begin{array}{c}\text { less affected by } \\
\text { anthropogenic } \\
\text { disturbance. }\end{array}$ \\
\hline Beijing $6, *$ & $\mathrm{H}$ & $\mathrm{H}$ & $\mathrm{H}$ & $\mathrm{H}$ & $\mathrm{L}$ & $\mathrm{L}$ & $\mathrm{L}$ & $\mathrm{L}$ & $\begin{array}{l}\text { Historical use of } \\
\text { PTEs in gardens. } \\
\text { Use of organic }\end{array}$ \\
\hline Sevilla ${ }^{7}$ & - & $\mathrm{H}$ & $\mathrm{H}$ & $\mathrm{H}$ & - & $\mathrm{L}$ & $\mathrm{L}$ & $\mathrm{L}$ & $\begin{array}{l}\text { amendments in } \\
\text { gardens. }\end{array}$ \\
\hline
\end{tabular}

${ }^{1}$ Brtnický et al. [23], ${ }^{2}$ Apostoae [25], ${ }^{3}$ Apostoae et al. [28], ${ }^{4}$ Imperato et al. [9], ${ }^{5}$ Biasioli et al. [32], ${ }^{6}$ Xia et al. [4], ${ }^{7}$ Ruiz-Cortes et al. [57],

* Significant $(p<0.05)$.

Although the botanical garden was significantly more contaminated with PTEs (Figure 5), its soil was significantly ( $p=0.05$, Tukey HSD test) less phytotoxic than in the park. The garden soil's phytotoxicity was found in only $27 \%$ of samples with a maximum inhibition value of $23 \%$ (Figure 4). In the park, $80 \%$ of samples with phytotoxicity reached $93 \%$ [23]. The lower toxicity of the botanical garden soil despite higher soil contamination may be attributed to higher activity of soil organisms. Organisms living in the soil of botanical gardens are not exposed to the extreme conditions (e.g., soil degradation due to trampling) experienced in public urban parks intensively used for recreation. More stable and favourable conditions can stimulate soil organisms' activity and reduce the toxicity or even degrade some pollutants [58]. This correlates with the results presented by Lorenz and Kandeler [59], who found higher microbial biomass and microbial activity in urban gardens with natural mixed substrates on loess compared to urban public parks. However, further large-scale research is needed on this topic to verify this hypothesis. Another reason for the lower soil toxicity in the botanical garden may be the higher nutrient content resulting from using fertilisers which could diminish the possible toxic effects. This hypothesis is consistent with the stimulation of green algae and S. alba growth (Figure 4). Finally, significantly higher $\mathrm{pH}$ in botanical garden soil compared to the park pH levels (Figure 5) could limit the concentration of PTEs in aqueous extracts and reduce their bioavailability for the tested organisms.

Trees are critical components of UGS and their protection ensuring that people gain the benefits trees provide should be priority [13]. The absence of such stresses for vegetation induced by soil toxicity may contribute to a more effective provision of ecosystem services [20] of botanical gardens compared to urban parks. As a result, the importance of botanical gardens and arboretums may be higher and more beneficial to public health. On the other hand, elevated PTE levels in the soil can be riskier for regular botanical garden visitors. The comparison and evaluation of benefits and potential threats should be the subject of further research.

\section{Conclusions}

Though the botanical garden soil assessments indicated serious contamination with $\mathrm{Cd}, \mathrm{Pb}$ and $\mathrm{Zn}$, all PTE contents were below the soil quality standards. The sources of contaminants were predominantly from traffic, historically deposited construction and demolition waste and agrochemicals. The soil does not pose a severe ecotoxicological risk 
to aquatic organisms, although the content of $\mathrm{Ni}$, as a potentially hazardous element for crustaceans, should be monitored. Prevailing growth stimulation of the S. alba indicated only slight soil phytotoxicity. Though few studies exist with similar findings and results are often disregarded, the hypothesis of a higher contamination of botanical and ornamental gardens compared to urban parks was confirmed. Because its indications appear globally, more attention needs to be paid to urban botanical and ornamental gardens as UGS potentially more burdened with contamination. Soil ecotoxicity of the botanical garden was low and not as risky as in the neighbouring urban park. The reasons for this need a more detailed investigation.

Author Contributions: Conceptualization, V.P. and M.B. (Martin Brtnicky); methodology, V.P., J.H.; software, T.B. and M.B. (Marie Balkova); validation, M.R., R.L. and M.B. (Martin Brtnicky); formal analysis, V.P. and M.B. (Marie Balkova); investigation, V.P.; resources, J.H. and M.B. (Martin Brtnicky); data curation, V.P. and T.B.; writing-original draft preparation, V.P.; writing—review and editing, J.H., M.B. (Martina Buckova) and M.R.; visualization, M.B. (Marie Balkova); supervision, M.B. (Martin Brtnicky), R.L. and M.R.; project administration, M.B. (Martin Brtnicky) and J.H.; funding acquisition, M.B. (Martin Brtnicky). All authors have read and agreed to the published version of the manuscript.

Funding: This research was financially supported by the Technology Agency of the Czech Republic under project TL01000286 (City parks as a quality social and natural environment for life) and by and the Ministry of Education, Youth and Sports of the Czech Republic under the project FCH-S-21-7398.

Institutional Review Board Statement: Not applicable.

Informed Consent Statement: Not applicable.

Data Availability Statement: The data presented in this study are available on request from the corresponding author.

Acknowledgments: The authors would also like to thank Michal Pavlík for his help and willingness to explore the history of the botanical garden.

Conflicts of Interest: The authors declare no conflict of interest.

\section{References}

1. Rodrigues, S.; Urquhart, G.; Hossack, I.; Pereira, M.E.; Duarte, A.C.; Davidson, C.; Hursthouse, A.; Tucker, P.; Roberston, D. The influence of anthropogenic and natural geochemical factors on urban soil quality variability: A comparison between Glasgow, UK and Aveiro, Portugal. Environ. Chem. Lett. 2009, 7, 141-148. [CrossRef]

2. Cheng, H.; Li, M.; Zhao, C.; Li, K.; Peng, M.; Qin, A.; Cheng, X. Overview of trace metals in the urban soil of 31 metropolises in China. J. Geochem. Explor. 2014, 139, 31-52. [CrossRef]

3. Ajmone-Marsan, F.; Biasioli, M. Trace elements in soils of urban areas. Water Air Soil Pollut. 2010, 213, 121-143. [CrossRef]

4. Xia, X.; Chen, X.; Liu, R.; Liu, H. Heavy metals in urban soils with various types of land use in Beijing, China. J. Hazard. Mater. 2011, 186, 2043-2050. [CrossRef] [PubMed]

5. Cachada, A.; Dias, A.C.; Pato, P.; Mieiro, C.; Rocha-Santos, T.; Pereira, M.E.; da Silva, E.F.; Duarte, A.C. Major inputs and mobility of potentially toxic elements contamination in urban areas. Environ. Monit. Assess. 2013, 185, 279-294. [CrossRef] [PubMed]

6. Setälä, H.; Francini, G.; Allen, J.A.; Jumpponen, A.; Hui, N.; Kotze, D.J. Urban parks provide ecosystem services by retaining metals and nutrients in soils. Environ. Pollut. 2017, 231, 451-461. [CrossRef]

7. Li, X.; Poon, C.S.; Liu, P.S. Heavy metal contamination of urban soils and street dusts in Hong Kong. Appl. Geochem. 2001, 16, 1361-1368. [CrossRef]

8. Meng, Z.; Li, Y.; Zhang, D.; Zhang, L. Pollution and ecological risk assessment of heavy metal elements in urban soil. In Proceedings of the 2011 International Symposium on Water Resource and Environmental Protection, Xi'an, China, 20-22 May 2011; IEEE: New York, NY, USA, 2011; Volume 3, pp. 1686-1689. [CrossRef]

9. Imperato, M.; Adamo, P.; Naimo, D.; Arienzo, M.; Stanzione, D.; Violante, P. Spatial distribution of heavy metals in urban soils of Naples city (Italy). Environ. Pollut. 2003, 124, 247-256. [CrossRef]

10. Martín, J.R.; De Arana, C.; Ramos-Miras, J.J.; Gil, C.; Boluda, R. Impact of 70 years urban growth associated with heavy metal pollution. Environ. Pollut. 2015, 196, 156-163. [CrossRef]

11. Livesley, S.J.; McPherson, E.G.; Calfapietra, C. The urban forest and ecosystem services: Impacts on urban water, heat, and pollution cycles at the tree, street, and city scale. J. Environ. Qual. 2016, 45, 119-124. [CrossRef]

12. Kabisch, N.; Kraemer, R.; Masztalerz, O.; Hemmerling, J.; Püffel, C.; Haase, D. Impact of summer heat on urban park visitation, perceived health and ecosystem service appreciation. Urban For. Urban Green. 2021, 60, 127058. [CrossRef] 
13. Cavender, N.; Donnelly, G. Intersecting urban forestry and botanical gardens to address big challenges for healthier trees, people, and cities. Plants People Planet 2019, 1, 315-322. [CrossRef]

14. Mexia, T.; Vieira, J.; Príncipe, A.; Anjos, A.; Silva, P.; Lopes, M.; Freitas, C.; Santos-Reis, M.; Correia, O.; Branquinho, C.; et al. Ecosystem services: Urban parks under a magnifying glass. Environ. Res. 2018, 160, 469-478. [CrossRef]

15. Qin, H.; Hong, B.; Jiang, R.; Yan, S.; Zhou, Y. The Effect of Vegetation Enhancement on Particulate Pollution Reduction: CFD Simulations in an Urban Park. Forests 2019, 10, 373. [CrossRef]

16. Guo, G.; Wu, F.; Xie, F.; Zhang, R. Spatial distribution and pollution assessment of heavy metals in urban soils from southwest China. J. Environ. Sci. 2012, 24, 410-418. [CrossRef]

17. Huzlík, J.; Hegrová, J.; Effenberger, K.; Ličbinský, R.; Brtnický, M. Air Quality in Brno City Parks. Atmosphere 2020, 11, 510. [CrossRef]

18. Onianwa, P.C. Roadside topsoil concentrations of lead and other heavy metals in Ibadan, Nigeria. Soil Sediment Contam. 2001, 10, 577-591. [CrossRef]

19. Urošević, M.A.; Vuković, G.; Jovanović, P.; Vujičić, M.; Sabovljević, A.; Sabovljević, M.; Tomašević, M. Urban background of air pollution: Evaluation through moss bag biomonitoring of trace elements in Botanical garden. Urban For. Urban Green. 2017, 25, 1-10. [CrossRef]

20. Burges, A.; Alkorta, I.; Epelde, L.; Garbisu, C. From phytoremediation of soil contaminants to phytomanagement of ecosystem services in metal contaminated sites. Int. J. Phytorem. 2018, 20, 384-397. [CrossRef] [PubMed]

21. Urrutia-Goyes, R.; Argyraki, A.; Ornelas-Soto, N. Assessing Lead, Nickel, and Zinc Pollution in Topsoil from a Historic Shooting Range Rehabilitated into a Public Urban Park. Int. J. Environ. Res. Public Health 2017, 14, 698. [CrossRef] [PubMed]

22. Gu, Y.G.; Gao, Y.P. Bioaccessibilities and health implications of heavy metals in exposed-lawn soils from 28 urban parks in the megacity Guangzhou inferred from an in vitro physiologically-based extraction test. Ecotoxicol. Environ. Saf. 2018, 148, 747-753. [CrossRef]

23. Brtnický, M.; Pecina, V.; Hladký, J.; Radziemska, M.; Koudelková, Z.; Klimánek, M.; Richtera, L.; Adamcová, D.; Elbl, J.; Galiová, M.V.; et al. Assessment of phytotoxicity, environmental and health risks of historical urban park soils. Chemosphere 2019, 220, 678-686. [CrossRef]

24. Han, Q.; Wang, M.; Cao, J.; Gui, C.; Liu, Y.; He, X.; He, Y.; Liu, Y. Health risk assessment and bioaccessibilities of heavy metals for children in soil and dust from urban parks and schools of Jiaozuo, China. Ecotoxicol. Environ. Saf. 2020, 191, 110157. [CrossRef]

25. Apostoae, L. Heavy metal contents in the soil of the Botanical Garden in Iaşi, Romania. Carpathian J. Earth Environ. Sci. 2016, 11, 519-528.

26. Hofmann, M.M.; Fleischmann, A.; Renner, S.S. Changes in the bee fauna of a German botanical garden between 1997 and 2017 , attributable to climate warming, not other parameters. Oecologia 2018, 187, 701-706. [CrossRef] [PubMed]

27. BGCI. About Botanic Gardens. Botanic Gardens Conservation International (BGCI). 2019. Available online: https://www.bgci: about/about-botanic-garden/ (accessed on 24 June 2020).

28. Apostoae, L.; Radu, E.; Iancu, O.G. Spatial distribution and assessment of heavy metal pollution in the soils of Copou Park, Iasi, Romania. Analele Stiintifice de Universitatii AI Cuza din Iasi. Sect. 2. Geologie 2013, 59, 23.

29. Carrus, G.; Scopelliti, M.; Panno, A.; Lafortezza, R.; Colangelo, G.; Pirchio, S.; Ferrini, F.; Salbitano, F.; Agrimi, M.; Portoghesi, L.; et al. Different Way to Stay in Touch with 'Urban Nature': The Perceived Restorative Qualities of Botanical Gardens. Front. Psychol. 2017, 8, 914. [CrossRef] [PubMed]

30. Chen, G.; Sun, W. The role of botanical gardens in scientific research, conservation, and citizen science. Plant Divers. 2018, 40, 181-188. [CrossRef] [PubMed]

31. Orecchio, S. Contamination from polycyclic aromatic hydrocarbons (PAHs) in the soil of a botanic garden localized next to a former manufacturing gas plant in Palermo (Italy). J. Hazard. Mater. 2010, 180, 590-601. [CrossRef] [PubMed]

32. Biasioli, M.; Grčman, H.; Kralj, T.; Madrid, F.; Díaz-Barrientos, E.; Ajmone-Marsan, F. Potentially toxic elements contamination in urban soils. J. Environ. Qual. 2007, 36, 70-79. [CrossRef]

33. ISO 11466:1995. Soil Quality -Extraction of Trace Elements Soluble in Aqua Regia; International Organization for Standardization: Geneva, Switzerland, 1995.

34. ČSN ISO 10523. Water Quality_Determination of $p H$; Czech Office for Standards, Metrology and Testing: Prague, Czech Republic, 2010.

35. Müller, G. Index of geoaccumulation in sediments of the Rhine River. Geojournal 1969, 2, 108-118.

36. García-Carmona, M.; Romero-Freire, A.; Aragón, M.S.; Peinado, F.M. Effectiveness of ecotoxicological tests in relation to physicochemical properties of $\mathrm{Zn}$ and $\mathrm{Cu}$ polluted Mediterranean soils. Geoderma 2019, 338, 259-268. [CrossRef]

37. ČSN EN ISO 6341. Water Quality_Determination of the Inhibition of the Mobility of Daphnia Magna Straus (Cladocera, Crustacea)—Acute Toxicity Test; Czech Office for Standards, Metrology and Testing: Prague, Czech Republic, 2013.

38. ČSN EN ISO 8692. Water Quality_Fresh Water Algal Growth Inhibition Test with Unicellular Green Algae; Czech Office for Standards, Metrology and Testing: Prague, Czech Republic, 2012.

39. Metodický Pokyn Odboru Odpadi ke Stanovení Ekotoxicity Odpadi̊; Ministry of the Environment of the Czech Republic: Prague, Czech Republic, 2007.

40. Franke, R. Smooth interpolation of scattered data by local thin plate splines. Comput. Math. Appl. 1982, 8, 273-281. [CrossRef]

41. Mitáš, L.; Mitášová, H. General variational approach to the interpolation problem. Comput. Math. Appl. 1988, 16, 983-992. [CrossRef] 
42. R Core Team. R: A Language and Environment for Statistical Computing. R Foundation for Statistical Computing: Vienna, Austria. Available online: http:/ / www.R-project.org/ (accessed on 16 November 2020).

43. VROM. Circular on Target Values and Intervention Values for Soil Remediation. Dutch Ministry of Housing Spatial Planning and Environment (VROM); VROM: Hague, The Netherlands, 2013.

44. Liu, L.; Liu, Q.; Ma, J.; Wu, H.; Qu, Y.; Gong, Y.; Yang, S.; An, Y.; Zhou, Y. Heavy metal(loid)s in the topsoil of urban parks in Beijing, China: Concentrations, potential sources, and risk assessment. Environ. Pollut. 2020, 260, 114083. [CrossRef]

45. Wang, C.; Liu, H.; Zhang, Y.; Zou, C.; Anthony, E.J. Review of arsenic behavior during coal combustion: Volatilization, transformation, emission and removal technologies. Prog. Energy Combust. Sci. 2018, 68, 1-28. [CrossRef]

46. Wei, B.; Jiang, F.; Li, X.; Mu, S. Contamination levels assessment of potential toxic metals in road dust deposited in different types of urban environment. Environ. Earth Sci. 2010, 61, 1187-1196. [CrossRef]

47. Werkenthin, M.; Kluge, B.; Wessolek, G. Metals in European roadside soils and soil solution-A review. Environ. Pollut. 2014, 189, 98-110. [CrossRef]

48. Bretzel, F.; Calderisi, M. Metal contamination in urban soils of coastal Tuscany (Italy). Environ. Monit. Assess. 2006, 118, 319-335. [CrossRef]

49. Malkoc, S.; Yazıc1, B.; Savas Koparal, A. Assessment of the levels of heavy metal pollution in roadside soils of Eskisehir, Turkey. Environ. Toxicol. Chem. 2010, 29, 2720-2725. [CrossRef] [PubMed]

50. Xie, H.; Li, J.; Zhang, C.; Tian, Z.; Liu, X.; Tang, C.; Han, Y.; Liu, W. Assessment of heavy metal contents in surface soil in the Lhasa-Shigatse-Nam Co area of the Tibetan Plateau, China. Bull. Environ. Contam. Toxicol. 2014, 93, 192-198. [CrossRef] [PubMed]

51. Maisto, G.; Manzo, S.; De Nicola, F.; Carotenuto, R.; Rocco, A.; Alfani, A. Assessment of the effects of Cr, Cu, Ni and Pb soil contamination by ecotoxicological tests. J. Environ. Monit. 2011, 13, 3049-3056. [CrossRef] [PubMed]

52. Nys, C.; Versieren, L.; Cordery, K.I.; Blust, R.; Smolders, E.; De Schamphelaere, K.A.C. Systematic Evaluation of Chronic MetalMixture Toxicity to Three Species and Implications for Risk Assessment. Environ. Sci. Technol. 2017, 51, 4615-4623. [CrossRef] [PubMed]

53. Deleebeeck, N.M.; De Schamphelaere, K.A.; Janssen, C.R. A novel method for predicting chronic nickel bioavailability and toxicity to Daphnia magna in artificial and natural waters. Environ. Toxicol. Chem. Int. J. 2008, 27, 2097-2107. [CrossRef] [PubMed]

54. Ardestani, M.M.; Van Straalen, N.M.; Van Gestel, C.A.M. The relationship between metal toxicity and biotic ligand binding affinities in aquatic and soil organisms: A review. Environ. Pollut. 2014, 195, 133-147. [CrossRef]

55. Martí, E.; Sierra, J.; Cáliz, J.; Montserrat, G.; Vila, X.; Garau, M.A.; Cruañas, R. Ecotoxicity of Cr, Cd, and Pb on Two Mediterranean Soils. Arch. Environ. Contam. Toxicol. 2013, 64, 377-387. [CrossRef]

56. Aruoja, V.; Kurvet, I.; Dubourguier, H.C.; Kahru, A. Toxicity testing of heavy-metal-polluted soils with algaeSelenastrum capricornutum: A soil suspension assay. Environ. Toxicol. 2004, 19, 396-402. [CrossRef]

57. Ruiz-Cortes, E.; Reinoso, R.; Díaz-Barrientos, E.; Madrid, L. Concentrations of potentially toxic metals in urban soils of Seville: Relationship with different land uses. Environ. Geochem. Health 2005, 27, 465-474. [CrossRef]

58. Zhu, X.; Chen, B.; Zhu, L.; Xing, B. Effects and mechanisms of biochar-microbe interactions in soil improvement and pollution remediation: A review. Environ. Pollut. 2017, 227, 98-115. [CrossRef]

59. Lorenz, K.; Kandeler, E. Biochemical characterization of urban soil profiles from Stuttgart, Germany. Soil Biol. Biochem. 2005, 37, 1373-1385. [CrossRef] 